\title{
Global unification of Business Valuation \\ Standards
}

Elżbieta Izabela Szczepankiewicz, Ph. D. Poznań University of Economics, Department of Accounting

\section{Introduction}

In many countries, business valuation specialists must accept certain fundamental principles stipulated in the standards. Standardization reduces bias in valuations, making them easier to compare and verify. This is why business valuation standards have been used for many years in the USA, Canada and many other countries. Standards used in the said countries were developed by organizations of valuation professionals, i.e. accountants, auditors, appraisers and/or specialized business valuation companies. Business Valuation Standards determine the necessary scope of knowledge and qualifications of a valuator, as well as the methodology of valuation.

The purpose of this article is to review the structure and scope of the most important Business Valuation Standards used globally. The second part also analyzes Polish regulations related to business valuation, and assesses the degree of their convergence with leading global standards. The article presents the problem of the professional competence of the persons which are involved in business valuation in the world and Poland. Research 
method adopted in the study is to analyze the most important standards in the word and inference.

\section{Structure of key Business Valuation Standards in the world}

The most famous the Business Valuation Standards were published in the United States of America, Canada, the Europe (Belgium), Hong Kong, Australia, New Zealand. In Europe, the Business Valuation Standards developed the European Group of Valuers' Associations in Belgium. In Canada, this standards draw up the Canadian Institute of Chartered Business Valuators. In Hong Kong, the Business Valuation Standards published the Hong Kong Business Valuation Forum. In Australia, the Standards of Business Valuation developed the Accounting Professional \& Ethical Standards Board. In New Zealand, this standards draw up the Institute of Chartered Accountants of New Zealand.

The American Business Valuation Standards are developed by three organizations: the National Association of Certified Valuation Analysts (NACVA); the Institute of Business Appraisers (IBA) and the American Society of Appraisers (ASA). Each of them develops their own standards, in compliance with higher level standards published by:

1. The Appraisal Foundation (AF),

2. The American Institute of Certified Public Accountants (AICPA),

3. The Canadian Institute of Chartered Business Valuators (CICBV).

The AF accredited by the US Congress as the source of valuation standards. The AF developed the Uniform Standards of Professional Appraisal Practice (USPAP).

An analysis of the Business Valuation Standards in the word allows one to notice a progressing internationalization of this standards developments worldwide, manifesting itself through gradual unification of the standards. Many standards by different organizations already have similar scope and structure. In 2011, for example, the NACVA and the IBA published developed jointly the new standards by a team representing both organizations. The new standards are compatible of the AICPA's Statement on Standards for Valuation Services No. 1, as well as the AF's Uniform Standards of Professional Appraisal Practice . This represents first step for unification of Business Valuation Standards.

The basic elements of the NACVA Professional Standards (2011) and the IBA Professional Standards (2011) to: General Standards; Ethical Standards; Scope of Services; Development Standards; Reporting Standards. The scope and structure of ASA Standards is somewhat different. The basic elements the ASA 
Business Valuation Standards (2009) to: ASA Business Valuation Standards (BVS), Statements on ASA Business Valuation Standards (SBVS), Advisory Opinions (AO) and Procedural Guidelines (PG).

Table 1 presents the scope of the NACVA Professional Standards, the IBA Professional Standards and the ASA Business Valuation Standards.

\section{Table 1. The scope of the NACVA Standards, the IBA Standards and the ASA Standards}

\begin{tabular}{|c|c|c|c|}
\hline $\begin{array}{c}\text { NACVA } \\
\text { Professional Standards } \\
\text { (NACVA, USA) } \\
\text { Revised 2011 }\end{array}$ & $\begin{array}{c}\text { IBA Professional } \\
\text { Standards } \\
\text { (IBA, USA) Revised } 2011\end{array}$ & \multicolumn{2}{|c|}{$\begin{array}{l}\text { ASA Business Valuation Standards } \\
\text { (ASA, USA) Revised } 2009\end{array}$} \\
\hline \multicolumn{2}{|l|}{$\begin{array}{l}\text { I. INTRODUCTION } \\
\text { A. Preamble }\end{array}$} & \multicolumn{2}{|c|}{ GENERAL PREAMBLE } \\
\hline \multicolumn{2}{|c|}{ II. GENERAL AND ETHICAL STANDARDS } & \multicolumn{2}{|c|}{ ASA BUSINESS VALUATION } \\
\hline \multicolumn{2}{|c|}{ A. Integrity and Objectivity } & \multicolumn{2}{|c|}{ STANDARDS (BVS) } \\
\hline \multicolumn{2}{|c|}{ B. Professional Competence } & \multirow[t]{2}{*}{ BVS-I } & General Requirements for \\
\hline \multicolumn{2}{|c|}{ C. Due Professional Care } & & Developing a Business \\
\hline \multicolumn{2}{|c|}{$\begin{array}{l}\text { D. Understandings and Communications with } \\
\text { Clients }\end{array}$} & \\
\hline \multicolumn{2}{|c|}{ E. Planning and Supervision } & & BVS-II \\
\hline \multicolumn{2}{|l|}{ F. Sufficient Relevar } & \multicolumn{2}{|l|}{ BVS-III } \\
\hline \multicolumn{2}{|l|}{ G. Confidentiality } & \multirow{2}{*}{\multicolumn{2}{|c|}{ 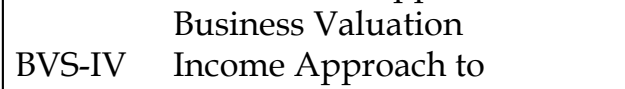 }} \\
\hline \multirow{2}{*}{\multicolumn{2}{|c|}{$\begin{array}{l}\text { H. Acts Discreditable } \\
\text { I. Client Interest }\end{array}$}} & & \\
\hline & & \multicolumn{2}{|c|}{ Business Valuation } \\
\hline \multicolumn{2}{|l|}{ J. Financial Interest } & \multirow{2}{*}{\multicolumn{2}{|c|}{$\begin{array}{ll}\text { BVS-V } & \text { Market Approach to Business } \\
\text { Valuation }\end{array}$}} \\
\hline \multicolumn{2}{|l|}{ III. SCOPE OF SERVICES } & & \\
\hline \multirow{2}{*}{\multicolumn{2}{|c|}{$\begin{array}{l}\text { A. Applicability } \\
\text { B. Valuation Services }\end{array}$}} & \multicolumn{2}{|c|}{ BVS-VI Reaching a Conclusion of } \\
\hline & & \multicolumn{2}{|c|}{ Value } \\
\hline \multicolumn{2}{|c|}{ 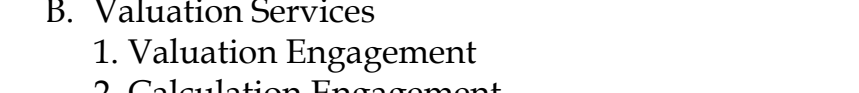 } & \multicolumn{2}{|c|}{$\begin{array}{l}\text { BVS-VII Valuation Discounts and } \\
\text { Premiums }\end{array}$} \\
\hline \multicolumn{2}{|l|}{ C. Other Services } & \multicolumn{2}{|c|}{ BVS-VIII Comprehensive Written } \\
\hline \multicolumn{2}{|c|}{ D. Jurisdictional Exception } & \multicolumn{2}{|c|}{ Business Valuation Report } \\
\hline \multicolumn{2}{|c|}{ IV. DEVELOPMENT STANDARDS } & \multicolumn{2}{|c|}{ BVS-IX Intangible Asset Valuation } \\
\hline B. Expression of Value & & GLOSSA & $\mathbf{R Y}$ \\
\hline C. Reliability of Data & & & \\
\hline D. Scope Limitations & & STATEM & IENTS ON ASA BUSINESS \\
\hline E. Use of Specialist & & VALUAT & ION STANDARDS (SBVS) \\
\hline $\begin{array}{l}\text { F. Approaches and Met } \\
\text { G. Identification }\end{array}$ & & SBVS-1 & $\begin{array}{l}\text { Guideline Public Company } \\
\text { Method }\end{array}$ \\
\hline H. Fundamental Analys & & SBVS-2 & Guideline Transactions \\
\hline I. Documentation & & & Method \\
\hline
\end{tabular}




\section{REPORTING STANDARDS}

A. General

B. Form of Report

C. Contents of Report

1. Detailed Reports

2. Summary Reports

3. Calculation Reports

4. Statement that the Report is in Accordance with (NACVA / IBA) Professional Standards

D. Litigation Engagements Reporting Standards

VI. INTERNATIONAL GLOSSARY

VII. EFFECTIVE DATE

APPPENDIX
ADVISORY OPINIONS (AO)

AO-1 Financial Consultation and

Advisory Services

PROCEDURAL GUIDELINES (PG)

PG-1 Litigation Support: Role of the Independent Financial Export

PG-2 Valuation of Partial

Ownership Interests

Source: Author's own study based on (IBA Professional..., 2011; NACVA Professional..., 2011; ASA Business..., 2009)

Other Business Valuation Standards differ in terms of content and scope of regulation. TEGoVA's Standards, for example, apply only to property valuation. Table 2 presents the scope of the Statement on Standards for Valuation Services (issued by the AICPA), the Standard No. 110 (issued by the CICBV) and the European Valuation Standards (issued by the TEGoVA).

Table 2. The scope of the AICPA Statement on Standards for Valuation Services, the CICBV Practice Standard No. 110 and the EGVA European Valuation Standards

\begin{tabular}{|c|c|c|}
\hline $\begin{array}{l}\text { Statement on Standards for } \\
\text { Valuation Services } \\
\text { (AICPA, USA) } \\
\text { Revised 2007 }\end{array}$ & $\begin{array}{l}\text { Standards No } 110 \text { Valuation } \\
\text { Report Standards and } \\
\text { Recommendations } \\
\text { (CICBV, Canada) } \\
\text { Revised } 2009 \text { and } 2010\end{array}$ & $\begin{array}{l}\text { European Valuation } \\
\text { Standards } \\
\text { (TEGoVA, Belgium) } \\
\text { Revised } 2009\end{array}$ \\
\hline $\begin{array}{l}\text { - Foreword } \\
\text { - Statement on Standards for } \\
\text { Valuation Services No. 1, } \\
\text { Valuation of a Business, } \\
\text { Business Ownership } \\
\text { Interest, Security, or } \\
\text { Intangible Asset } \\
\text { - Introduction and Scope } \\
\text { - Overall Engagement } \\
\text { Considerations } \\
\text { - Development }\end{array}$ & $\begin{array}{l}\text { VALUATION REPORTS } \\
\text { - Report Disclosure Standards } \\
\text { and Recommendations } \\
\text { - Report Introduction } \\
\text { - Report Definitions } \\
\text { - Report Scope of Review } \\
\text { - Report Disclosure } \\
\text { - Report Restrictions and } \\
\text { Qualifications } \\
\text { - Conclusion }\end{array}$ & $\begin{array}{l}\text { Introduction } \\
\text { Part } 1 \\
\text { EUROPEAN VALUATION } \\
\text { STANDARDS } \\
\text { EVS1 - Market Value } \\
\text { EVS2 - Valuation Bases Other } \\
\quad \text { than Market Value } \\
\text { EVS3 - The Qualified Valuer } \\
\text { EVS4 - The Valuation Process }\end{array}$ \\
\hline
\end{tabular}


- The Valuation Report

- Effective Date

Appendix A: Illustrative List of Assumptions and Limiting Conditions for a Business Valuation

Appendix B: International Glossary of Business Valuation Terms

Appendix C: Glossary of Additional Terms

Interpretation No. 1, „Scope of Applicable Services" of Statement on Standards for Valuation Services No.1, Valuation of a Business, Business
Appendix A to Standard No. 110

VALUATION REPORTS PREPARED FOR PURPOSES OF SECURITIES LEGISLATION, REGULATION OR POLICIES

- Introduction

- General

- Independence and

Qualifications

- Fundamental Financial

Information

- Valuation Calculations

Appendix B to Standard No. 110 VALUATION FOR FINANCIAL REPORTING

- Introduction

- General

- Fundamental Information

- Business Combinations and the Valuation of Intangibles

- Impairment of Goodwill and Intangible Assets
EVS5 - Reporting the

Valuation

Part 2

EUROPEAN VALUATION APPLICATIONS

EVA1 -Valuation for the Purpose of Financial Reporting

EVA2 - Valuation for Lending Purposes

EVA3 - Property Valuation for Securitisation Purposes

EVA4 - Assessment of Insurable Value

EVA5 - Application of Investment Value (Worth) for Individual Investors

Glossary

Source: Author's own study based on (Statement on Standards..., 2007 Standards No 110..., 2009-2010; European Valuation..., 2009)

Table 3 presents the scope of the APES 225 (issued by the APESB in Australia), the AES-2 (issued by the ICANZ in New Zealand) and the Business Valuation Standards (issued by the BVF in Hong Kong).

Table 3. The scope of the APES 225, AES-2 and the Business Valuation Standards (issued by the Hong Kong BVF)

\begin{tabular}{|c|c|c|}
\hline $\begin{array}{l}\text { APES } 225 \text { - Valuation } \\
\text { Services } \\
\text { (APESB, Australia) } \\
\text { Revised } 2008\end{array}$ & $\begin{array}{c}\text { Advisory Engagement Standard } 2 \text { (AES-2) } \\
\text { Independent Business Valuation } \\
\text { Engagements } \\
\text { (ICANZ, New Zealand) Revised } 2003\end{array}$ & $\begin{array}{l}\text { Business Valuation } \\
\text { Standards } \\
\text { (BVF, Hong Kong) } \\
\text { Revised } 2005\end{array}$ \\
\hline $\begin{array}{l}\text { - Paragraphs } \\
\text { - Scope and application } \\
\text { - Definitions } \\
\text { - Fundamental } \\
\text { responsibilities of } \\
\text { Members }\end{array}$ & $\begin{array}{l}\text { 1. Introduction } \\
\text { - Purpose } \\
\text { - Applicability } \\
\text { - Effective Date } \\
\text { 2. Definitions }\end{array}$ & $\begin{array}{l}\text { 1. Introduction } \\
\text { 2. Scope } \\
\text { 3. Glossary }\end{array}$ \\
\hline
\end{tabular}


- Public interest

- Professional Independence

- Professional competence and due care Confidentiality

- Professional Engagement and other matters

- Reporting

- Documentation

- Use of a glossary of business valuation terms

- Professional fees

- Conformity with International Pronouncements

Appendix 1: Examples of what constitutes a Valuation Service
3. Standards for Independent Business Valuation Engagements

- General Principles Relating to an Inde-pendent Business Valuation Engagement

- Remuneration

- Terms of the Engagement

- Planning

- Use of Another Expert

- Performance Standards and Procedures

- Documentation

- Reporting

- Circulation of Draft Reports

- Content of an Independent Business Valuation Report

- Identification of the Person or Persons to whom the Report is Addressed

- Valuation Date

- Date of the Report

- Statement of any Restrictions on the Scope of Work

- Statement of any Interests or Relationships Between the Member and the Business or Interested Parties to the Valuation

- Business Valuation Conclusion

- Statement of the Key Sources of Information Relied On

4. Appendix: Comparison of AES-2 with International and Australian Standards

Source: Author's own study based on (APES 225..., 2008; Advisory Engagement..., 2003; Business Valuation..., 2005)

All Business Valuation Standards include the basic business or property valuation principles, describe the content of the Business Valuation Report and the principles of applying various valuation methods.

\section{Approaches, Methods and Report of Business Valuation in the Standards}

The NACVA Professional Standards (2011), The IBA Professional Standards (2011), The ASA Business Valuation Standards (2009) and of the AICPA Statement on Standards for Valuation Services No. 1 list three valuation approaches and methods based on: 
- Asset-Based Approach to Business Valuation,

- Income Approach to Business Valuation,

- Market Approach to Business Valuation.

The Methods to Business Valuation described in detail in the Standards.

The Canadian Standard No. 110 (2009-2010), published by the CICBV lists the following valuation approaches and methods:

- Asset Based Approaches - Fair Market Value of Assets and Liabilities, Liquidation-Based Value of Assets and Liabilities,

- Capitalized Earnings/Cash Flow Approach - Unadjusted Earnings/Cash Flow, Normalization Adjustments, Tax Calculations, Financing Costs, Sustaining Capital Reinvestments, Cash Flow Items, Discount Rates, Multiples and Capitalization Rates, Sustainable Earnings/Cash Flow,

- Discounted Cash Flow Approach - Forecast Assumptions, Forecast Cash Floks, Terminal/Residual Value, Discount Rates, Multiples and Capitalization Rates, Sensitivity Analysis,

- Redundant Assets,

- other approaches.

None of the Business Valuation Standards discussed here uses algorithms for selecting a business valuation method. The AICPA Statement on Standards for Valuation Services No. 1 (2007) stipulate that the valuator should choose valuation methods depending on the entity subject to such valuation. He/she should align results arrived at using various methods, assess the reliability of results taking into account information collected in the process and then decide whether the final value will be based on one method only, or on a combination of several methods. The NACVA Professional Standards (2011) and the IBA Professional Standards (2011) require the valuator to list all the methods considered and to state the reasons for discarding some of them and selecting others.

The ASA Business Valuation Standards (2009) and the Principles of Appraisal Practice (2012), issued by the ASA, also indicate that the procedure and method for determining the particular value in question is a matter for the appraiser to decide. The selection of and reliance on appropriate methods and procedures depends on the professional judgment of the appraiser and not on any prescribed formula. Good appraisal practice requires that the method selected be adequate for the purpose, embrace consideration of all the factors that have a bearing on the value, and be presented in a clear and logical manner. The appraiser's judgment may be presented either in general terms or in terms of mathematical weighting of the indicated values reflected in the conclusion. In any case, the appraiser should provide the rationale for the selection or weighting of the 
method or methods relied on in reaching the conclusion. (ASA Business ...2009; Principles ...2012)

The Business Valuation Report according to the NACVA Professional Standards (2011) and the IBA Professional Standards (2011) should contain: project brief, market and industry analysis, company information, financial analysis, business valuation and conclusions. Many standards use tools for verifying the report's compliance, such as check lists and other methodological supports.

\section{Qualifications of business valuators in the word}

Business Appraisal Report is a report that meets the requirements of American standards. In the USA and Canada, the qualifications of persons who prepare Business Appraisal Reports are formally regulated (Table 4). The NACVA, IBA and ASA certificates are in compliance with the Uniform Standards of Professional Appraisal Practice, imposed by the US Congress.

Importantly, American regulations do not determine the qualifications of persons who prepare Business Valuation Reports (e.g. stock exchange valuations prepared by brokerages, etc.). Polish regulations do not reserve business valuation authorship for any specific professional group.

Table 4. Certificates of Business Appraisal Report authors

\begin{tabular}{|c|c|c|c|}
\hline Certificates & $\begin{array}{l}\text { Organization, } \\
\text { which grants }\end{array}$ & $\begin{array}{l}\text { The basic } \\
\text { requirements }\end{array}$ & Additional requirements \\
\hline $\begin{array}{l}\text { CVA } \\
\text { Certified Valuation Analyst }\end{array}$ & \multirow{2}{*}{$\begin{array}{l}\text { NACVA } \\
\text { National } \\
\text { Association } \\
\text { of Certified } \\
\text { Valuation } \\
\text { Analysts }\end{array}$} & $\begin{array}{l}\text { Certified Public } \\
\text { Accountants } \\
\text { Exam }\end{array}$ & \multirow[t]{2}{*}{ The practice of valuation } \\
\hline $\begin{array}{l}\text { GVA } \\
\text { Government Valuation Analyst }\end{array}$ & & Exam & \\
\hline $\begin{array}{l}\text { CBA } \\
\text { Certified Business Appraiser }\end{array}$ & \multirow{3}{*}{$\begin{array}{l}\text { IBA } \\
\text { Institute of } \\
\text { Business } \\
\text { Appraisers }\end{array}$} & Exams & $\begin{array}{l}\text { Evaluation of } 2 \text { Business } \\
\text { Appraisal Reports }\end{array}$ \\
\hline $\begin{array}{l}\text { MCBA } \\
\text { Master Certified Business } \\
\text { Appraiser }\end{array}$ & & Exams & $\begin{array}{l}\text { Evaluation of } 2 \text { Business } \\
\text { Appraisal Reports }\end{array}$ \\
\hline $\begin{array}{l}\text { FIBA } \\
\text { Fellow of the Institute of } \\
\text { Business Appraisers }\end{array}$ & & - & Practice of valuation \\
\hline
\end{tabular}




\begin{tabular}{|c|c|c|c|}
\hline $\begin{array}{l}\text { ASA } \\
\text { Accredited Senior Appraiser }\end{array}$ & $\begin{array}{l}\text { ASA } \\
\text { American Society } \\
\text { of Appraisers }\end{array}$ & Exam & $\begin{array}{l}\text { Practice of valuation (5 } \\
\text { years) and assessment of } \\
\text { Business Appraisal Report }\end{array}$ \\
\hline $\begin{array}{l}\text { AM } \\
\text { Accredited Member }\end{array}$ & & Exams & $\begin{array}{l}\text { Practice of valuation } \\
\text { ( } 2 \text { years) and assessment } \\
\text { of two Business Appraisal } \\
\text { Reports }\end{array}$ \\
\hline $\begin{array}{l}\text { FASA } \\
\text { Fellow of the American Society } \\
\text { of Appraisers }\end{array}$ & & - & Practice of valuation \\
\hline $\begin{array}{l}\text { ABV } \\
\text { Accredited in Business } \\
\text { Valuation }\end{array}$ & $\begin{array}{l}\text { AICPA } \\
\text { American Institute } \\
\text { of Certified Public } \\
\text { Accountants }\end{array}$ & $\begin{array}{l}\text { Certified Public } \\
\text { Accountant } \\
\text { Exam }\end{array}$ & $\begin{array}{l}\text { Practice of valuation } \\
\text { (10 Reports) }\end{array}$ \\
\hline $\begin{array}{l}\text { CBV } \\
\text { Chartered Business Valuator }\end{array}$ & $\begin{array}{l}\text { CICBV } \\
\text { The Canadian } \\
\text { Institute } \\
\text { of Chartered } \\
\text { Business } \\
\text { Valuators }\end{array}$ & Exams & $\begin{array}{l}\text { Practice of valuation } \\
\text { ( } 2 \text { years) }\end{array}$ \\
\hline
\end{tabular}

Source: Author's own study based on (www.nacva.com., www.appraisers.org, www.go-iba.org, www.aicpa.org; www.cicbv.ca)

\section{Polish regulations on the business valuation}

One of the laws in effect in Poland is the regulation of 2011 on company analysis preceding the sale of shares owned by the Treasury. The regulation determines the scope of the analysis for the purposes of valuation of businesses subject only to commercialization or privatization.

Furthermore, the Polish Federation of Appraisers' Associations (PFSRM) adopted Standards and Notes on real property appraisal, being part of the General National Appraisal Principles. In April 2011, the Federation adopted Interpretation Note 5 (,General Business Valuation Principles”). An analysis of Note 5 leads one to believe that to some extent it has been based on western Business Valuation Standards. Note 5 sets out business valuation methods and approaches and defines the content of a Business Valuation Reports and a list of key issues to be addressed by its author. When preparing the valuation, valuators are not limited by strictly codified regulations. However, they are expected 
to address a number of key issues and present rationale for the methodology selected. Polish specialists are in agreement as far as the basic valuation methods are concerned: carrying value, fair value and discount rate. Thus, the Federation recommends a "soft version" of a Business Valuation Standards. Standards must use only the members of the Polish Federation of Appraisers' Associations. This regulations does not apply to other experts.

However, apart from contractual scope of activities, a uniform Business Valuation Standards system is missing. It would allow one to:

- verify or document the qualifications of Business Valuation Report authors,

- unify the valuation process and define the minimum scope of activities to be carried out in its course,

- impose a list of issues to be addressed by the valuator,

- define Business Valuation Report structure.

Therefore, the fundamental regulations of a Polish Business Valuation Standards should be modeled after NACVA Standards and IBA Standards.

\section{Conclusions}

The most leading global standards that can be helpful in building a uniform Polish Business Valuation Standards. An analysis of the global Business Valuation Standards allows one to notice a progressing internationalization of Business Valuation Standards developments worldwide, manifesting itself through gradual unification of the standards. Many standards by different organizations already have similar scope and structure.

The article also analyzes Polish regulations related to business valuation, and assesses the degree of their convergence with leading global standards. Polish regulations do not reserve business valuation authorship for any specific professional group. Adoption of such a standard could reduce the degree of bias currently found in business valuations. Valuations made on the basis of identical requirements become comparable and easier to verify. Determining the qualifications of business valuators will allow their customers to easily verify the degree of professionalism of the valuation.

\section{Abstract}

\section{Global unification of Business Valuation Standards}

The paper analyzes the most important standards in the word that can be helpful in building a uniform Polish Business Valuation Standards. The article presents also structure and scope of 
Standards. The paper also analyzes Polish regulations related to business valuation, and assesses the degree of their convergence with leading standards in the word. The paper also analyzes Polish regulations related to business valuation, and assesses the degree of their convergence with leading global standards. Research method adopted in the study is to analyze the most important standards in the word and inference.

Keywords: Business Valuation Standards.

\section{Streszczenie}

Proces unifikacji standardów wyceny przedsiębiorstw na świecie W artykule dokonano analizy najważniejszych wiodących standardów oszacowania wartości przedsiębiorstw na świecie, które mogą być pomocne $\mathrm{w}$ budowaniu polskich standardów wyceny. Przedstawiono strukturę i zakres takich standardów. W artykule przeprowadzono również analizę polskich obecnie obowiązujących regulacji $\mathrm{w}$ zakresie wyceny przedsiębiorstw. Oceniono poziom ich unifikacji $\mathrm{z}$ wiodącymi standardami zachodnimi. Metodą badawczą przyjętą w opracowaniu jest analiza wiodących światowych standardów wyceny przedsiębiorstwa oraz wnioskowanie.

\section{Słowa}

kluczowe: standardy wyceny przedsiębiorstw.

\section{References}

1. Advisory Engagement Standard 2 (AES-2) - Independent Business Valuation Engagements (2003), Institute of Chartered Accountants of New Zealand, New Zealand.

2. APES 225 Valuation Services (2008), The Accounting Professional \& Ethical Standards Board.

3. ASA Business Valuation Standards (2009), American Society of Appraisers, USA.

4. Business Valuation Standards (2005), The Hong Kong Business Valuation Forum, The Hong Kong.

5. Certificates of the AICPA, www.aicpa.org (online 20-03-2013).

6. Certificates of the ASA, www.appraisers.org (online 20-03-2013).

7. Certificates of the CICBV, www.cicbv.ca (online 20-03-2013). 
8. Certificates of the IBA, www.go-iba.org (online 20-03-2013).

9. Certificates of the NACVA, www.nacva.com. (online 20-03-2013).

10. European Valuation Standards (2009), The European Group of Valuers' Associations, Belgium.

11. IBA Professional Standards (2011), The Institute of Business Appraisers, USA.

12. NACVA Professional Standards (2011), The National Association of Certified Valuation Analysts, USA.

13. Powszechne Krajowe Zasady Wyceny, Nota Interpretacyjna Nr 5 (NI 5) (2011)Ogólne Zasady Wyceny Przedsiębiorstw, Polska Federacja Stowarzyszeń Rzeczoznawców Majątkowych, Warszawa.

14. Practice Standards No 110 (2009-2010), The Canadian Institute of Chartered Business Valuations, Canada.

15. Practice Standards No 120 (2010), The Canadian Institute of Chartered Business Valuations, Canada.

16. Practice Standards No 130 (2009), The Canadian Institute of Chartered Business Valuations, Canada.

17. Principles of Appraisal Practice and Code of Ethics (2012), American Society of Appraisers, USA.

18. Rozporządzenie Rady Ministrów z dnia 30 maja 2011 r. w sprawie analiz spótki przeprowadzanych przed zaoferowaniem do zbycia akcji należacych do Skarbu Państwa (Dz.U. 2011, Nr 114, poz. 663).

19. Statement on Standards for Valuation Services (2007), American Institute of Certified Public Accountants, USA.

20. Uniform Standards of Professional Appraisal Practice (2012-2013), The Appraisal Foundation, USA. 